Our Nature 2013, 11(2): 116-125

\title{
Nitrogen and Phosphorous Budget Analysis of Carp Based Polyculture Ponds in Chitwan, Nepal
}

\author{
S. Gurung, M.K. Shrestha and N.P. Pandit \\ Institute of Agriculture and Animal Science (IAAS), Tribhuvan University, Rampur, Chitwan, Nepal \\ E-mail: panditnp@hotmail.com
}

Received: 13.11.2013; Accepted: 16.12.2013

\begin{abstract}
An experiment was conducted in 12 earthen ponds of $200 \mathrm{~m}^{2}$ at Kathar VDC, Chitwan, Nepal for 270 days to analyze the productivity and nutrient budget in some carp based polyculture systems. The experiment was conducted in a completely randomized design with four treatments in triplicate each: a) Carps only or control (7000 fish/ha) $\left.\left(\mathrm{T}_{1}\right) ; \mathrm{b}\right)$ Carps $(7000 / h a)+$ tilapia $(3000 / h a)\left(\mathrm{T}_{2}\right)$; c) Carps $(7000 / \mathrm{ha})+$ tilapia $(3000 / \mathrm{ha})+$ sahar (500/ha) $\left(\mathrm{T}_{3}\right)$; and d) Carps (7000/ha) + tilapia (3000/ha) + sahar (1000/ha) $\left(\mathrm{T}_{4}\right)$. Silver carp (Hypophthalmichthys molitrix), bighead carp (Aristichthys nobilis), common carp (Cyprinus carpio), grass carp (Ctenopharyngodon idella), rohu (Labeo rohita) and mrigal (Cirrhinus mrigala) of mean stocking size 3.0, 4.2, 10.0, 18.8, 10.5, $2.2 \mathrm{~g}$, respectively were stocked in all ponds at the ratio of $4: 2: 1: 1: 1: 1$. The mean stocking size of Nile tilapia (Oreochromis niloticus) and sahar (Tor putitora) were 9.7 and $3.4 \mathrm{~g}$, respectively. The ponds were fertilized weekly with urea and di-ammonium phosphate @ $4 \mathrm{~g} \mathrm{~N}$ and 1 $\mathrm{g} \mathrm{P} / \mathrm{m}^{2} /$ day. Fish were fed with locally made pellet feed $(20 \% \mathrm{CP})$ once in an alternate day at @ 2\% body weight. At harvest, the extrapolated fish yield ranged from 1.5 to 1.7 t/ha/year in different treatments, without significant differences among treatments (P>0.05). Inclusion of sahar in Nile tilapia ponds decreased recruits by 63 to $72 \%$. There were no significant differences in water quality parameters among treatments, except dissolved oxygen concentration, which was significantly lower in $T_{1}$ and $T_{3}$ than $T_{2}$ and $\mathrm{T}_{4}(\mathrm{p}<0.05)$. Both nitrogen and phosphorous were gained from fish species and lost from soil and water. There were no significant differences in nitrogen and phosphorous contents of all inputs and outputs among treatments. The unaccounted nitrogen and phosphorous loss ranged from $9.8-17.1 \%$ and $51.2-64.4 \%$, respectively. The nitrogen and phosphorous required for producing $1 \mathrm{~kg}$ fish ranged from 337.5-375.9 $\mathrm{g}$ and 130.3-150.9 $\mathrm{g}$, without significant difference among treatments. The nitrogen and phosphorous discharged for producing $1 \mathrm{~kg}$ fish ranged from 1.59-4.35 $\mathrm{g}$ and 1.6-9.3 $\mathrm{g}$, respectively.
\end{abstract}

Key words: Nile tilapia, Sahar, carp, body weight, nutrient budget, Chitwan

\section{Introduction}

Semi-intensive carp polyculture system is the major aquaculture system in Nepal (Pradhan and Pantha, 1995). It is an established and recommended system in tropical and subtropical region of Nepal using fertilized ponds with partial feed supplementation. The carp species used in Nepalese polyculture system are common carp (Cyprinus carpio), silver carp (Hypophthalmichthys molitrix), bighead carp (Aristichthys nobilis), grass carp (Ctenopharyngodon idella), rohu (Labeo 
rohita), naini/mrigal (Cirrhinus mrigala), and bhakur/catla (Catla catla). Though all seven species are recommended in certain ratios with a combined density of 7,00010,000 fish/ha (Pandey et al., 2007), fingerlings of all species are rarely available when needed for stocking. In most of the cases, the number of species cultured ranges from four to six. Addition of well-proven species (such as Nile tilapia and Sahar) with increased stocking density into the existing carp production system can have a positive impact by increasing productivity and economic value (Shrestha et al., 2011). Nile tilapia (Oreochromis niloticus) was introduced in Nepal in 1985 (Pantha, 1993), however, it remained in government control for more than 10 years (Shrestha and Bhujel, 1999). Since 1996, some works on tilapia were initiated at the Institute of Agriculture and Animal Science (IAAS) under Tribhuvan University. Experiments conducted included: polyculture of tilapia and common carp (Shrestha and Bhujel, 1999), mixed size culture of tilapia (Mandal and Shrestha, 2001), and polyculture of grass carp with tilapia (Pandit et al., 2004). As mixed sex tilapia was used for culture, recruitment control was a problem. African catfish (Clarias gariepinus) and snakehead (Channa striatus) are often used to control tilapia fry (Mishra, 2002; Yi et al., 2004). Sahar (Tor putitora) an omnivore, which feeds on filamentous algae, insect larvae, small mollusks, and periphyton on rocks (Shrestha, 1997) were explored to study its predation capacity on tilapia fries (Shrestha et al., 2011). The IAAS has worked on tilapia and sahar combinations in polyculture to control excessive recruitment of tilapia and also to provide additional species to increase productivity and to promote culture of high value fish that are indigenous.

Nutrient enrichment of pond waters is an essential management practice in aquaculture (Boyd, 1990; Pillay, 1999). Intensification in aquaculture through the high stocking density and inputs in ponds not only results in increased fish yields, but also improves efficiency in land use and water consumption. However, the most concerned problem resulted from the intensive aquaculture is waste effluents which contain highly concentrated nutrients, organic matter and suspended solids. The discharge of this nutrient-rich water, an environmental regulatory concern in many developed countries, may result in the deteriorated quality of receiving waters (Yi et al., 2003). Thus, nutrient budget analysis is necessary for any new aquaculture system before it is recommended to farmers. The nutrient-budget analysis is generally used to assess the relationships between feed nutrients input, nutrient retention in the cultured fish, and nutrient release to the environment in relation to a given production (Gowen et al., 1988). The nutrient budget provides the rate of material delivery to the pond (input), the rate of material removal from pond (output) and the rate of change of material mass within the pond (storage). Although many studies have examined the nutrient budget of freshwater fish and shrimp ponds (Yi et al., 2003; Khoi and Fotedar, 2010), no work has been conducted on nutrient budget analysis of carp-based polyculture ponds. The purposes of this study were to assess the production potential of some new carpbased polyculture systems and to assess the 
nitrogen and phosphorous budget of these systems.

\section{Materials and methods}

This experiment was conducted in 12 earthen ponds of $200 \mathrm{~m}^{2}$ at Kathar VDC, Chitwan, Nepal for 270 days to analyze the productivity and nutrient budget in some carp based polyculture systems. The experiment was conducted in a completely randomized design with four treatments in triplicate each: a) Carps only or control (7000 fish/ha) $\left(\mathrm{T}_{1}\right)$; b) Carps (7000/ha) + tilapia (3000/ha) $\left(\mathrm{T}_{2}\right)$; c) Carps (7000/ha) + tilapia (3000/ha) + Sahar (500/ha) $\left(\mathrm{T}_{3}\right)$; and d) Carps (7000/ha) + tilapia (3000/ha) + Sahar (1000/ha) $\left(\mathrm{T}_{4}\right)$. The experimental ponds were completely drained about 2 weeks before fish stocking. Immediately after water drainage, hydrated lime $(\mathrm{Ca}$ $\left.(\mathrm{OH})_{2}\right)$ was applied to each pond at the rate of $10 \mathrm{~kg}$ for $200 \mathrm{~m}^{2}$ pond area. The ponds were sun-dried for 2-3 days after liming then filled up with fresh canal water. Then, ponds were fertilized at the rate of $4 \mathrm{~kg} \mathrm{~N}$ and $1 \mathrm{~kg} \mathrm{P} / \mathrm{ha} /$ day for 7 days with diammonium phosphate (DAP) $(18 \% \mathrm{~N}$ and $\left.46 \% \mathrm{P}_{2} \mathrm{O}_{5}\right)$ and urea $(46 \% \mathrm{~N})$. Pond water depth was maintained $1.0 \mathrm{~m}$ with occasional topping to compensate the losses due to evaporation and leaching. The fish were stocked in experimental ponds after a week of fertilization. Silver carp, bighead carp, common carp, grass carp, rohu and mrigal of mean stocking size 3.0, 4.2, 10.0, 18.8, $10.5,2.2 \mathrm{~g}$, respectively were stocked in all ponds at the ratio of $4: 2: 1: 1: 1: 1$. The mean stocking size of Nile tilapia and sahar were 9.7 and $3.4 \mathrm{~g}$, respectively. The experimental ponds were fertilized weekly with Urea and DAP at the rate of $4 \mathrm{~kg} \mathrm{~N}$ and
$1 \mathrm{~kg} \mathrm{P} / \mathrm{ha} / \mathrm{day}$ to maintain the pond water fertility during experimental period. Pellet feed having 20\% CP was provided @ $2 \%$ total body weight. Feeding trays were fixed in each pond and feed were provided on alternate day basis at 9-10 am. Feed rations were adjusted based on monthly sampling weight of fishes. At harvest, fish were counted and separated, and their batch weight was taken.

Water quality parameters (DO, pH, temperature, transparency and water depth) were measured in situ weekly at 7.00-9.00 am. Composite water samples were used for nutrient analysis. For total nitrogen and phosphorous analysis, water samples were taken into IAAS laboratory and analyzed within $12 \mathrm{hrs}$ of sampling (AOAC, 1980). Sediment samples were collected with 10$\mathrm{cm}$ diameter plastic tubes from top $5 \mathrm{~cm}$ of each compartment before initial pond filling and after fish harvest. Total nitrogen and phosphorous in sediment samples, feed samples and fish samples at stocking and harvest were analyzed using the methods described by Yoshida et al. (1976). The nutrient budgets for nitrogen and phosphorus in all treatments were calculated as follows based on inputs from water, stocked fish, fertilizers and pellet feed; and losses in harvested fish, discharged water and sediment.

Nutrients (N/P) in feed $=$ nutrients concentration in feed $x$ total amount of feed supplied

Nutrients $(\mathrm{N} / \mathrm{P})$ in water $=$ nutrients concentration in water $x$ total amount of water

Nutrients $(\mathrm{N} / \mathrm{P})$ in soil sediment $=$ nutrients 
concentration in soil $x$ total amount of soil measured

Nutrients (N/P) in fish $=$ nutrients concentration in fish $x$ total fish biomass

Nutrients (N/P) required to produce $1 \mathrm{~kg}$ fish $=$ Nutrient input $($ feed + fertilizer $) /$ total fish production

Nutrients (N/P) discharged to produce $1 \mathrm{~kg}$ fish $=$ Nutrient loss in water $/$ total fish production

Unaccounted nutrients $=$ total nutrient input - total nutrient output

Data were analyzed statistically by one-way ANOVA using SPSS (version 16.0) statistical software package (SPSS Inc., Chicago). Microsoft excel was used for data calculation. Mean comparison were done by LSD at $5 \%(\mathrm{P}<0.05)$ significance level. All means were given with \pm standard error (S.E.).

\section{Results and discussion Fish production}

The production of carps, tilapia and sahar in different treatments are presented in table 1 . The extrapolated fish yield was ranged from 1.5 to $1.7 \mathrm{t} / \mathrm{ha} /$ year in different treatments without any significant differences among treatments $(\mathrm{P}>0.05)$. This production is lower than the average fish productivity of Nepal (3.3 t/ha/year; DoFD, 2011). The low fish production in all treatments might be due to the commencement of the experiment in newly constructed ponds and the absence of benthic organisms in the new ponds (Jayasinghe and de Silva, 1993). The number and total weight of tilapia recruits were highest in $T_{2}$, intermediate in $T_{3}$ and lowest in $\mathrm{T}_{4}$. This indicates that addition of sahar can effectively control the number of tilapia recruits. Yadav et al. (2007) and Shrestha et al. (2011) also reported that the number of tilapia recruits decreased linearly with increasing stocking density of sahar.

\section{Water quality}

Fortnightly means of water quality parameters of the experimental period are presented in table 2. Most of the water quality parameters, showed cyclic variation, but were within the recommended range for the growth performance of fishes used in the present experiment (Boyd, 1990). There were no significant differences in water quality parameters among treatments, except dissolved oxygen concentration. Dissolved oxygen was significantly lower in $\mathrm{T}_{1}$ and $\mathrm{T}_{3}$ than $\mathrm{T}_{2}$ and $\mathrm{T}_{4}(\mathrm{p}<0.05)$. The water temperature, $\mathrm{pH}$, dissolved oxygen and Secchi disk depth were ranged from 16.3 to $29.2^{\circ} \mathrm{C}, 7.6$ to $8.6,5.1$ to $11.9 \mathrm{mg} / \mathrm{L}$ and 15.3 to $50.0 \mathrm{~cm}$, respectively throughout the experimental period (Tab. 2). Similarly, total nitrogen and total phosphorous were ranged from 2.45 to 4.13 $\mathrm{mg} / \mathrm{L}$ and 0.76 to $3.25 \mathrm{mg} / \mathrm{L}$, respectively.

\section{Nutrient budget}

The TN and TP composition of all fish species, feeds, fertilizers and soils in different treatments are presented in table 3. There was variation in initial and final nutrient composition among different fish species. There were no significant differences in initial and final TN and TP levels in water among treatments $(\mathrm{P}>0.05)$. The initial TP level in $\mathrm{T}_{3}$ was significantly lower than other treatments. Similarly, the final TP level in $\mathrm{T}_{1}$ was significantly lower than other treatments (Tab. 3). The final TN 
S. Gurung, M.K. Shrestha and N.P. Pandit / Our Nature (2013), 11(2): 116-125

Table 1. Production of carps, tilapia and sahar in different treatments during the experimental period of 270 days $\left(\right.$ Mean \pm SE). Data based on $200 \mathrm{~m}^{2}$ water area. Mean values with same superscript in the same row are not significantly different $(\mathrm{P}>0.05)$.

\begin{tabular}{lcccc}
\hline \multirow{2}{*}{ Parameters } & \multicolumn{3}{c}{ Treatments } \\
\cline { 2 - 5 } & \multicolumn{1}{c}{$\mathbf{T}_{\mathbf{1}}$} & $\mathbf{T}_{\mathbf{2}}$ & $\mathbf{T}_{\mathbf{3}}$ & $\mathbf{T}_{\mathbf{4}}$ \\
\hline Carps (kg) & $23.0 \pm 1.0^{\mathrm{a}}$ & $17.0 \pm 4.0^{\mathrm{a}}$ & $15.0 \pm 5.0^{\mathrm{a}}$ & $15.0 \pm 1.0^{\mathrm{a}}$ \\
Nile tilapia & & & \\
Adult (kg) & - & $7.0 \pm 2.0^{\mathrm{a}}$ & $8.0 \pm 1.0^{\mathrm{a}}$ & $6.0 \pm 1.0^{\mathrm{a}}$ \\
Recruits (kg) & - & $1.14 \pm 0.20^{\mathrm{c}}$ & $0.40 \pm 0.05^{\mathrm{b}}$ & $0.04 \pm 0.01^{\mathrm{a}}$ \\
Sub-total Nile tilapia (kg) & - & $8.1 \pm 0.8^{\mathrm{a}}$ & $8.4 \pm 1.5^{\mathrm{b}}$ & $6.0 \pm 1.0^{\mathrm{c}}$ \\
Sahar (kg) & - & - & $0.3 \pm 0.1^{\mathrm{a}}$ & $0.6 \pm 0.2^{\mathrm{b}}$ \\
Total (kg) & $23.0 \pm 1.0^{\mathrm{a}}$ & $25.1 \pm 1.1^{\mathrm{a}}$ & $23.7 \pm 1.6^{\mathrm{a}}$ & $21.6 \pm 0.7^{\mathrm{a}}$ \\
Extrapolated yield (t/ha/year) & $1.6 \pm 0.1^{\mathrm{a}}$ & $1.7 \pm 0.1^{\mathrm{a}}$ & $1.6 \pm 0.1^{\mathrm{a}}$ & $1.5 \pm 0.0^{\mathrm{a}}$ \\
\hline
\end{tabular}

Table 2. Mean and range of water quality parameters in different treatments during the experimental period of 270 days $($ Mean \pm SE). Mean values with same superscript in the same row are not significantly different $(\mathrm{P}>0.05)$.

\begin{tabular}{|c|c|c|c|c|}
\hline \multirow{2}{*}{ Parameters } & \multicolumn{4}{|c|}{ Treatments } \\
\hline & $\mathbf{T}_{1}$ & $\mathbf{T}_{2}$ & $\mathbf{T}_{3}$ & $\mathbf{T}_{4}$ \\
\hline \multirow{2}{*}{ Water temperature $\left({ }^{\circ} \mathrm{C}\right)$} & $20.4 \pm 1.70^{\mathrm{a}}$ & $22.8 \pm 0.3^{\mathrm{a}}$ & $20.0 \pm 1.9^{\mathrm{a}}$ & $23.1 \pm 0.0^{\mathrm{a}}$ \\
\hline & $(16.3-28.7)$ & $(16.5-28.9)$ & $(17.1-29.2)$ & $(17.0-28.7)$ \\
\hline \multirow{2}{*}{ Dissolved oxygen $(\mathrm{mg} / \mathrm{L})$} & $7.7 \pm 0.3^{\mathrm{b}}$ & $8.6 \pm 0.23^{\mathrm{a}}$ & $7.7 \pm 0.3^{\mathrm{b}}$ & $8.4 \pm 0.1^{\mathrm{a}}$ \\
\hline & $(5.4-10.7)$ & $(6-12.5)$ & $(6.3-11.2)$ & $(5.1-11.9)$ \\
\hline \multirow{2}{*}{$\mathrm{pH}$} & 8.3 & 8.3 & 8.2 & 8.3 \\
\hline & $(7.7-8.6)$ & $(7.8-8.6)$ & $(7.7-8.6)$ & $(7.6-8.6)$ \\
\hline \multirow{2}{*}{ Secchi disk depth $(\mathrm{cm})$} & $26.7 \pm 1.7^{\mathrm{a}}$ & $28.7 \pm 1.3^{\mathrm{a}}$ & $29.3 \pm 2.1^{\mathrm{a}}$ & $28.9 \pm 1.5^{\mathrm{a}}$ \\
\hline & $(18.7-47.2)$ & $(17.5-54.2)$ & $(15-54.6)$ & $(17.5-50.3)$ \\
\hline \multirow{2}{*}{ Total nitrogen $(\mathrm{mg} / \mathrm{L})$} & $3.3 \pm 0.5^{\mathrm{a}}$ & $3.7 \pm 0.5^{\mathrm{a}}$ & $3.6 \pm 0.3^{\mathrm{a}}$ & $3.6 \pm 0.5^{\mathrm{a}}$ \\
\hline & $(2.5-4.3)$ & $(2.8-4.2)$ & $(2.9-4.0)$ & $(2.7-4.1)$ \\
\hline \multirow{2}{*}{ Total phosphorous (mg/L) } & $2.0 \pm 0.3^{\mathrm{a}}$ & $1.7 \pm 0.6^{\mathrm{a}}$ & $2.9 \pm 0.3^{\mathrm{a}}$ & $2.1 \pm 0.5^{\mathrm{a}}$ \\
\hline & $(1.5-2.5)$ & $(0.8-2.8)$ & $(2.3-3.3)$ & $(1.3-2.9)$ \\
\hline
\end{tabular}

and TP levels of soil sediments in all treatments were significantly higher than the initial level in all treatments $(\mathrm{p}<0.05)$. That might be due to the deposition of uneaten feed, fish faeces and other organic matters in the soil sediment. The results of the present study indicated that addition of tilapia and sahar in carp polyculture ponds did not result in significantly higher nutrient outputs in effluents or nutrients deposited in sediments $(\mathrm{P}>0.05)$.

Nitrogen budget in different treatments for 270 days culture period are given in table 4. There were no significant differences in nitrogen content of all inputs among treatments $(p>0.05)$. Results showed that the dominant nitrogen inputs were sediment and fertilizer in all treatments. The nitrogen input from fertilizer was 6.40 $\mathrm{kg} /$ pond in all treatments. Similarly, the nitrogen inputs from feed, water and soil ranged from 1.51-2.07, 0.66-0.74 and 12.00$18.00 \mathrm{~kg} /$ pond, respectively. The nitrogen inputs from all fish were $0.07-0.13 \mathrm{~kg} /$ pond. The total nitrogen input ranged from 20.64$27.33 \mathrm{~kg} /$ pond. There was no significant difference in nitrogen content of all outputs among different treatments $(p>0.05)$. The nitrogen output from water, soil and all fishes ranged from $0.76-0.80,16.00-22.00$ 
S. Gurung, M.K. Shrestha and N.P. Pandit / Our Nature (2013), 11(2): 116-125

Table 3. Moisture, TN and TP composition (\% dry matter bas is) of fishes, feeds, soils and water during stocking and harvest in different treatments (Mean \pm SE).

\begin{tabular}{|c|c|c|c|c|c|c|c|c|}
\hline \multirow{3}{*}{ Parameters } & \multicolumn{8}{|c|}{ Treatments } \\
\hline & \multicolumn{4}{|c|}{ At stocking } & \multicolumn{4}{|c|}{ At harvest } \\
\hline & $\overline{T_{1}}$ & $\overline{T_{2}}$ & T3 & $\mathbf{T}_{4}$ & $\overline{T_{1}}$ & $\mathbf{T}_{2}$ & $\overline{T 3}$ & $\overline{T_{4}}$ \\
\hline \multicolumn{9}{|l|}{$\overline{\text { Common carp }}$} \\
\hline Moisture & $71.7 \pm 1.8$ & $71.7 \pm 1.8$ & $71.7 \pm 1.8$ & $71.7 \pm 1.8$ & $70.5 \pm 1.6$ & $70.5 \pm 1.6$ & $70.5 \pm 1.6$ & $70.5 \pm 1.6$ \\
\hline $\mathrm{TN}$ & $8.9 \pm 0.4$ & $8.9 \pm 0.4$ & $8.9 \pm 0.4$ & $8.9 \pm 0.4$ & $7.3 \pm 0.1$ & $7.3 \pm 0.1$ & $7.3 \pm 0.1$ & $7.3 \pm 0.1$ \\
\hline $\mathrm{TP}$ & $2.3 \pm 0.1$ & $2.3 \pm 0.1$ & $2.3 \pm 0.1$ & $2.3 \pm 0.1$ & $1.6 \pm 0.1$ & $1.6 \pm 0.1$ & $1.6 \pm 0.1$ & $1.6 \pm 0.1$ \\
\hline \multicolumn{9}{|l|}{$\overline{\text { Bighead carp }}$} \\
\hline Moisture & 72.1 & 72.1 & 72.1 & 72.1 & 71.5 & 71.5 & 71.5 & 71.5 \\
\hline $\mathrm{TN}$ & $8.4 \pm 0.2$ & $8.4 \pm 0.2$ & $8.4 \pm 0.2$ & $8.4 \pm 0.2$ & $9.3 \pm 0.5$ & $9.3 \pm 0.5$ & $9.3 \pm 0.5$ & $9.3 \pm 0.5$ \\
\hline TP & $3.3 \pm 0.7$ & $3.3 \pm 0.7$ & $3.3 \pm 0.7$ & $3.3 \pm 0.7$ & $3.7 \pm 0.8$ & $3.7 \pm 0.8$ & $3.7 \pm 0.8$ & $3.7 \pm 0.8$ \\
\hline \multicolumn{9}{|l|}{ Grass carp } \\
\hline Moisture & 70.1 & 70.1 & 70.1 & 70.1 & 70.0 & 70.0 & 70.0 & 70.0 \\
\hline $\mathrm{TN}$ & $10.2 \pm 0.2$ & $10.2 \pm 0.2$ & $10.2 \pm 0.2$ & $10.2 \pm 0.2$ & $8.6 \pm 0.2$ & $8.6 \pm 0.2$ & $8.6 \pm 0.2$ & $8.6 \pm 0.2$ \\
\hline $\mathrm{TP}$ & $3.1 \pm 0.3$ & $3.1 \pm 0.3$ & $3.1 \pm 0.3$ & $3.1 \pm 0.3$ & $2.6 \pm 0.3$ & $2.6 \pm 0.3$ & $2.6 \pm 0.3$ & $2.6 \pm 0.3$ \\
\hline \multicolumn{9}{|l|}{ Silver carp } \\
\hline Moisture & $71.2 \pm 1.2$ & $71.2 \pm 1.2$ & $71.2 \pm 1.2$ & $71.2 \pm 1.2$ & $72.3 \pm 1.1$ & $72.3 \pm 1.1$ & $72.3 \pm 1.1$ & $72.3 \pm 1.1$ \\
\hline $\mathrm{TN}$ & $9.1 \pm 0.5$ & $9.1 \pm 0.5$ & $9.1 \pm 0.5$ & $9.1 \pm 0.5$ & $11.9 \pm 1.4$ & $11.9 \pm 1.4$ & $11.9 \pm 1.4$ & $11.9 \pm 1.4$ \\
\hline $\mathrm{TP}$ & $3.0 \pm 0.4$ & $3.0 \pm 0.4$ & $3.0 \pm 0.4$ & $3.0 \pm 0.4$ & $2.86 \pm 0.5$ & $2.86 \pm 0.5$ & $2.86 \pm 0.5$ & $2.86 \pm 0.5$ \\
\hline \multicolumn{9}{|l|}{$\overline{\text { Rohu }}$} \\
\hline Moisture & $70.2 \pm 1.5$ & $70.2 \pm 1.5$ & $70.2 \pm 1.5$ & $70.2 \pm 1.5$ & $69.0 \pm 1.5$ & $69.0 \pm 1.5$ & $69.0 \pm 1.5$ & $69.0 \pm 1.5$ \\
\hline $\mathrm{TN}$ & $10.4 \pm 0.2$ & $10.4 \pm 0.2$ & $10.4 \pm 0.2$ & $10.4 \pm 0.2$ & $10.2 \pm 0.1$ & $10.2 \pm 0.1$ & $10.2 \pm 0.1$ & $10.2 \pm 0.1$ \\
\hline $\mathrm{TP}$ & $3.5 \pm 0.0$ & $3.5 \pm 0.0$ & $3.5 \pm 0.0$ & $3.5 \pm 0.0$ & $3.0 \pm 0.3$ & $3.0 \pm 0.3$ & $3.0 \pm 0.3$ & $3.0 \pm 0.3$ \\
\hline \multicolumn{9}{|l|}{ Mrigal } \\
\hline Moisture & $71.5 \pm 1.3$ & $71.5 \pm 1.3$ & $71.5 \pm 1.3$ & $71.5 \pm 1.3$ & $70.8 \pm 1.7$ & $70.8 \pm 1.7$ & $70.8 \pm 1.7$ & $70.8 \pm 1.7$ \\
\hline $\mathrm{TN}$ & $10.2 \pm 0.4$ & $10.2 \pm 0.4$ & $10.2 \pm 0.4$ & $10.2 \pm 0.4$ & $11.0 \pm 0.4$ & $11.0 \pm 0.4$ & $11.0 \pm 0.4$ & $11.0 \pm 0.4$ \\
\hline $\mathrm{TP}$ & $2.6 \pm 0.1$ & $2.6 \pm 0.1$ & $2.6 \pm 0.1$ & $2.6 \pm 0.1$ & $1.6 \pm 0.3$ & $1.6 \pm 0.3$ & $1.6 \pm 0.3$ & $1.6 \pm 0.3$ \\
\hline \multicolumn{9}{|l|}{ Nile tilapia } \\
\hline Moisture & $72.1 \pm 1.1$ & $72.1 \pm 1.1$ & $72.1 \pm 1.1$ & $72.1 \pm 1.1$ & $71.2 \pm 1.4$ & $71.2 \pm 1.4$ & $71.2 \pm 1.4$ & $71.2 \pm 1.4$ \\
\hline $\mathrm{TN}$ & $9.0 \pm 0.3$ & $9.0 \pm 0.3$ & $9.0 \pm 0.3$ & $9.0 \pm 0.3$ & $10.3 \pm 0.3$ & $10.3 \pm 0.3$ & $10.3 \pm 0.3$ & $10.3 \pm 0.3$ \\
\hline TP & $2.6 \pm 0.1$ & $2.6 \pm 0.1$ & $2.6 \pm 0.1$ & $2.6 \pm 0.1$ & $2.2 \pm 0.2$ & $2.2 \pm 0.2$ & $2.2 \pm 0.2$ & $2.2 \pm 0.2$ \\
\hline \multicolumn{9}{|l|}{ Sahar } \\
\hline Moisture & $74.1 \pm 1.8$ & $74.1 \pm 1.8$ & $74.1 \pm 1.8$ & $74.1 \pm 1.8$ & $73.3 \pm 1.6$ & $73.3 \pm 1.6$ & $73.3 \pm 1.6$ & $73.3 \pm 1.6$ \\
\hline $\mathrm{TN}$ & $8.9 \pm 0.5$ & $8.9 \pm 0.5$ & $8.9 \pm 0.5$ & $8.9 \pm 0.5$ & $10.7 \pm 0.2$ & $10.7 \pm 0.2$ & $10.7 \pm 0.2$ & $10.7 \pm 0.2$ \\
\hline $\mathrm{TP}$ & $2.0 \pm 0.1$ & $2.0 \pm 0.1$ & $2.0 \pm 0.1$ & $2.0 \pm 0.1$ & $2.7 \pm 0.3$ & $2.7 \pm 0.3$ & $2.7 \pm 0.3$ & $2.7 \pm 0.3$ \\
\hline \multicolumn{9}{|l|}{ Feed } \\
\hline Moisture & $5.4 \pm 0.2$ & $5.4 \pm 0.2$ & $5.4 \pm 0.2$ & $5.4 \pm 0.2$ & & & & \\
\hline TN & $3.3 \pm 0.1$ & $3.3 \pm 0.1$ & $3.3 \pm 0.1$ & $3.3 \pm 0.1$ & & & & \\
\hline TP & $1.3 \pm 0.1$ & $1.3 \pm 0.1$ & $1.3 \pm 0.1$ & $1.3 \pm 0.1$ & & & & \\
\hline \multicolumn{9}{|l|}{ Soil } \\
\hline Moisture & 54.3 & 55.2 & 55.1 & 56.7 & 55.7 & 55.7 & 56.7 & 57.9 \\
\hline $\mathrm{TN}(\mathrm{g} / \mathrm{kg})$ & $0.6 \pm 0.3$ & $0.9 \pm 0.1$ & $0.9 \pm 0.2$ & $0.7 \pm 0.1$ & $0.8 \pm 0.2$ & $1.1 \pm 0.1$ & $1.0 \pm 0.4$ & $0.9 \pm 0.1$ \\
\hline $\mathrm{TP}(\mathrm{g} / \mathrm{kg})$ & $0.02 \pm 0.0$ & $0.02 \pm 0.0$ & $0.01 \pm 0.0$ & $0.02 \pm 0.0$ & $0.03 \pm 0.0$ & $0.05 \pm 0.0$ & $0.05 \pm 0.0$ & $0.05 \pm 0.0$ \\
\hline \multicolumn{9}{|l|}{ Water } \\
\hline $\mathrm{TN}(\mathrm{mg} / \mathrm{L})$ & $3.3 \pm 0.5$ & $3.7 \pm 0.5$ & $3.6 \pm 0.6$ & $3.6 \pm 0.6$ & $3.8 \pm 0.7$ & $3.9 \pm 0.7$ & $4.0 \pm 0.6$ & $4.0 \pm 0.6$ \\
\hline $\mathrm{TP}(\mathrm{mg} / \mathrm{L})$ & $1.4 \pm 0.3$ & $1.7 \pm 0.3$ & $1.9 \pm 0.3$ & $1.1 \pm 0.4$ & $1.8 \pm 0.3$ & $1.9 \pm 0.3$ & $2.1 \pm 0.3$ & $2.1 \pm 0.2$ \\
\hline
\end{tabular}


S. Gurung, M.K. Shrestha and N.P. Pandit / Our Nature (2013), 11(2): 116-125

Table 4. Nitrogen budget (in $\mathrm{kg}$ ) in different treatments for 270 days (Mean $\pm \mathrm{SE}$ ). Data based on $200 \mathrm{~m}^{2}$ water area. Mean values with same superscript in the same row are not significantly different $(\mathrm{P}>0.05)$.

\begin{tabular}{|c|c|c|c|c|}
\hline \multirow{2}{*}{ Parameters } & \multicolumn{4}{|c|}{ Treatments } \\
\hline & $\mathbf{T}_{1}$ & $\mathbf{T}_{2}$ & $\mathbf{T}_{3}$ & $\mathbf{T}_{4}$ \\
\hline \multicolumn{5}{|l|}{$\overline{\text { Inputs (kg) }}$} \\
\hline Feed & $1.51 \pm 0.15^{\mathrm{a}}$ & $2.07 \pm 0.27^{\mathrm{a}}$ & $2.00 \pm 0.32^{\mathrm{a}}$ & $1.72 \pm 0.12^{\mathrm{a}}$ \\
\hline Fertilizer & $6.40 \pm 0.00^{\mathrm{a}}$ & $6.40 \pm 0.00^{\mathrm{a}}$ & $6.40 \pm 0.00^{\mathrm{a}}$ & $6.40 \pm 0.00{ }^{\mathrm{a}}$ \\
\hline Water & $0.66 \pm 0.11^{\mathrm{a}}$ & $0.74 \pm 0.09^{\mathrm{a}}$ & $0.72 \pm 0.07{ }^{a}$ & $0.72 \pm 0.10^{\mathrm{a}}$ \\
\hline Soil & $12.00 \pm 2.31^{\mathrm{a}}$ & $18.00 \pm 3.67^{\mathrm{a}}$ & $18.00 \pm 4.67^{\mathrm{a}}$ & $14.00 \pm 1.33^{\mathrm{a}}$ \\
\hline Fish & $0.07 \pm 0.01^{\mathrm{a}}$ & $0.12 \pm 0.10^{\mathrm{a}}$ & $0.12 \pm 0.01{ }^{\mathrm{a}}$ & $0.13 \pm 0.01^{\mathrm{a}}$ \\
\hline Total inputs & $20.64 \pm 2.25^{\mathrm{a}}$ & $27.33 \pm 2.59^{\mathrm{a}}$ & $27.24 \pm 4.88^{\mathrm{a}}$ & $22.97 \pm 2.56^{\mathrm{a}}$ \\
\hline \multicolumn{5}{|l|}{ Outputs (kg) } \\
\hline Water & $0.76 \pm 0.19^{\mathrm{a}}$ & $0.78 \pm 0.12^{a}$ & $0.80 \pm 0.22^{\mathrm{a}}$ & $0.80 \pm 0.10^{\mathrm{a}}$ \\
\hline Soil & $16.00 \pm 2.40^{\mathrm{a}}$ & $22.00 \pm 2.52^{\mathrm{a}}$ & $20.00 \pm 4.62^{\mathrm{a}}$ & $18.00 \pm 2.85^{\mathrm{a}}$ \\
\hline Fish & $1.35 \pm 0.13^{\mathrm{a}}$ & $1.72 \pm 0.16^{\mathrm{a}}$ & $1.79 \pm 0.21^{\mathrm{a}}$ & $1.92 \pm 0.22^{\mathrm{a}}$ \\
\hline Unaccounted & $2.53 \pm 0.70^{\mathrm{a}}$ & $2.83 \pm 0.81^{\mathrm{a}}$ & $4.65 \pm 1.22^{\mathrm{k}}$ & $2.25 \pm 0.65^{\mathrm{a}}$ \\
\hline Total outputs & $20.64 \pm 3.12^{\mathrm{a}}$ & $27.33 \pm 2.89^{\mathrm{a}}$ & $27.24 \pm 5.18^{\mathrm{a}}$ & $22.97 \pm 2.36^{\mathrm{a}}$ \\
\hline $\mathrm{N}$ required for producing $1 \mathrm{~kg}$ fish $(\mathrm{g} / \mathrm{kg})$ & $343.9 \pm 30.2^{\mathrm{a}}$ & $337.5 \pm 25.6^{\mathrm{a}}$ & $354.4 \pm 22.4^{\mathrm{a}}$ & $375.9 \pm 27.5^{\mathrm{a}}$ \\
\hline $\mathrm{N}$ discharged for producing $1 \mathrm{~kg}$ fish $(\mathrm{g} / \mathrm{kg})$ & $4.4 \pm 1.2$ & $1.6 \pm 0.3$ & $3.4 \pm 0.5^{\mathrm{a}}$ & $3.7 \pm 0.4^{\mathrm{a}}$ \\
\hline
\end{tabular}

and $1.35-1.92 \mathrm{~kg} /$ pond, respectively. The unaccounted nitrogen loss in our study ranged from $2.25-4.65 \mathrm{~kg} /$ pond $(9.8-17.1 \%)$, which is significantly highest in $\mathrm{T}_{3}$ than other treatments. The unaccounted nitrogen loss in our study is comparable with 5.2$36 \%$ for $P$. monodon in a closed culture system (Thakur and Lin, 2003). However, it was lower than 32.5-39.3\% reported by Perez-Velazquez et al. (2008) in a zero water exchange culture system of $L$. vannamei. Nitrogen may have been lost through denitrifcation, ammonia volatilezation and / or diffusion at higher $\mathrm{pH}$ levels (Briggs and Funge-Smith, 1994). The nitrogen was gained from fish species and loosed in soil and water. The total nitrogen gain from fishes ranged from 1.3-1.8 $\mathrm{kg} /$ pond without any significant difference among treatments. Similarly, the total nitrogen loss from water and soil ranged from $0.04-0.10$ and 2.0-4.0 $\mathrm{kg} / \mathrm{pond}$, respectively (data not shown).The nitrogen required for producing $1 \mathrm{~kg}$ fish ranged from 337.45-375.93 g, without significant difference among treatments (Tab. 4). Similarly, the nitrogen discharged for producing $1 \mathrm{~kg}$ fish ranged from 1.59-4.35 $\mathrm{g}$, which is significantly lowest in $\mathrm{T}_{2}$ than other treatments.

Phosphorous budget in different treatments for 270 days culture period are given in table 5 . There were no significant differences in phosphorous content of all inputs among treatments ( $p>0.05)$, except in soil sediment. Results showed that the dominant phosphorous input was fertilizer in all treatments. The phosphorous input from fertilizer was $2.60 \mathrm{~kg} /$ pond in all 
Table 5. Phosphorous budget (in $\mathrm{kg}$ ) in different treatments for 270 days (Mean \pm SE). Data based on $200 \mathrm{~m}^{2}$ water area. Mean values with same superscript in the same row are not significantly different $(\mathrm{P}>0.05)$.

\begin{tabular}{|c|c|c|c|c|}
\hline \multirow{2}{*}{ Parameters } & \multicolumn{4}{|c|}{ Treatments } \\
\hline & $\mathbf{T}_{1}$ & $\mathbf{T}_{2}$ & $T_{3}$ & $\mathbf{T}_{4}$ \\
\hline \multicolumn{5}{|l|}{ Inputs (kg) } \\
\hline Feed & $0.58 \pm 0.06^{\mathrm{a}}$ & $0.67 \pm 0.03^{\mathrm{a}}$ & $0.77 \pm 0.12^{\mathrm{a}}$ & $0.66 \pm 0.05^{\mathrm{a}}$ \\
\hline Fertilizer & $2.60 \pm 0.00^{\mathrm{a}}$ & $2.60 \pm 0.00^{\mathrm{a}}$ & $2.60 \pm 0.00^{\mathrm{a}}$ & $2.60 \pm 0.00^{\mathrm{a}}$ \\
\hline Water & $0.28 \pm 0.06^{\mathrm{a}}$ & $0.34 \pm 0.08^{\mathrm{a}}$ & $0.38 \pm 0.06^{\mathrm{a}}$ & $0.22 \pm 0.05^{\mathrm{a}}$ \\
\hline Soil & $0.40 \pm 0.02^{\mathrm{a}}$ & $0.20 \pm 0.01^{\mathrm{b}}$ & $0.40 \pm 0.03^{\mathrm{a}}$ & $0.40 \pm 0.02^{\mathrm{a}}$ \\
\hline Fish & $0.04 \pm 0.00^{\mathrm{a}}$ & $0.13 \pm 0.01^{\mathrm{a}}$ & $0.09 \pm 0.01^{\mathrm{a}}$ & $0.16 \pm 0.00^{\mathrm{a}}$ \\
\hline Total inputs & $3.90 \pm 0.25^{\mathrm{a}}$ & $4.14 \pm 0.18^{\mathrm{a}}$ & $4.04 \pm 0.28^{\mathrm{a}}$ & $4.04 \pm 1.12^{\mathrm{a}}$ \\
\hline \multicolumn{5}{|l|}{ Outputs (kg) } \\
\hline Water & $0.36 \pm 0.05^{\mathrm{a}}$ & $0.38 \pm 0.10^{\mathrm{a}}$ & $0.42 \pm 0.08^{\mathrm{a}}$ & $0.42 \pm 0.26^{\mathrm{a}}$ \\
\hline Soil & $0.6 \pm 0.15^{\mathrm{b}}$ & $1.00 \pm 0.10^{\mathrm{a}}$ & $1.00 \pm 0.08^{\mathrm{a}}$ & $1.00 \pm 0.15^{\mathrm{a}}$ \\
\hline Fish & $0.43 \pm 0.05^{\mathrm{a}}$ & $0.46 \pm 0.05^{\mathrm{a}}$ & $0.45 \pm 0.02^{\mathrm{a}}$ & $0.55 \pm 0.06^{\mathrm{a}}$ \\
\hline Unaccounted & $2.51 \pm 0.35^{\mathrm{a}}$ & $2.30 \pm 0.20^{\mathrm{a}}$ & $2.17 \pm 0.20^{\mathrm{a}}$ & $2.07 \pm 0.26^{\mathrm{a}}$ \\
\hline Total outputs & $3.90 \pm 0.45^{\mathrm{a}}$ & $4.14 \pm 0.48^{\mathrm{a}}$ & $4.04 \pm 0.38^{\mathrm{a}}$ & $4.04 \pm 0.72^{\mathrm{a}}$ \\
\hline $\mathrm{P}$ required for producing $1 \mathrm{~kg}$ fish $(\mathrm{g} / \mathrm{kg})$ & $138.3 \pm 12.1^{\mathrm{a}}$ & $130.3 \pm 10.3^{\mathrm{a}}$ & $142.2 \pm 11.7^{\mathrm{a}}$ & $150.9 \pm 13.5^{2}$ \\
\hline $\mathrm{P}$ discharged for producing $1 \mathrm{~kg}$ fish $(\mathrm{g} / \mathrm{kg})$ & $3.5 \pm 0.25^{b}$ & $1.6 \pm 0.13^{\mathrm{c}}$ & $1.7 \pm 0.10^{\mathrm{c}}$ & $9.3 \pm 0.59^{\mathrm{a}}$ \\
\hline
\end{tabular}

treatments. Similarly, the phosphorous inputs from feed, water and soil were ranged from $0.58-0.77,0.22-0.38$ and 0.20 $0.40 \mathrm{~kg} /$ pond, respectively. The phosphorrous inputs from all fish were 0.04-0.16 $\mathrm{kg} /$ pond. The total phosphorous input was ranged from $3.90-4.14 \mathrm{~kg} /$ pond. There was no significant difference in phosphorous content of all outputs among different treatments $(p>0.05)$, except in soil sediment (Tab. 5). The phosphorous output from water, soil and all fishes were ranged from $0.36-0.42,0.60-1.00$ and $0.43-0.55 \mathrm{~kg} /$ pond, respectively. The unaccounted phosphorous loss in our study ranged from 2.07-2.51 $\mathrm{kg} /$ pond $(51.2-64.4 \%)$, which is higher than $6.6-24.6 \%$ for $P$. latisulkatus in a recirculation aquaculture system (Khoi and Fotedar, 2010) and with $32.5-39.3 \%$ reported by Perez-Velazquez et al. (2008) in a zero water exchange culture system of $L$. vannamei. Like nitrogen, phosphorous may have been lost through volatilization and/or diffusion; however, we could not speculate the causes of such high amount of TP loss.

Like nitrogen, the phosphorous was gained from fish species and loosed in soil and water. The total phosphorous gained ranged from $0.33-0.39 \mathrm{~kg} /$ pond without any significant difference among treatments. Similarly, the total phosphorous loss from water and soil ranged from $0.04-0.20$ and $0.2-0.8 \mathrm{~kg} /$ pond, respectively (data not shown). The phosphorous required for producing $1 \mathrm{~kg}$ fish ranged from 130.28 $150.93 \mathrm{~g}$, without significant difference among treatments (Tab. 5). The phosphorous discharged for producing $1 \mathrm{~kg}$ 
fish ranged from 1.6-9.3 $\mathrm{g}$, which is significantly highest in $\mathrm{T}_{4}$, intermediate in $\mathrm{T}_{2}$ and $\mathrm{T}_{3}$ and lowest in $\mathrm{T}_{1}$.

In conclusion, this paper provides an insight on the nitrogen and phosphorous budgeting of some new carp based polyculture systems. These results could be useful for future research to formulate fertilization and feeding strategies in these polyculture systems.

\section{Acknowledgements}

The authors wish to acknowledge the help of the Department of Aquaculture, IAAS, Rampur, Chitwan, Nepal for providing laboratory facilities, and fish farmers of Kathar, Chitwan for providing their ponds for research. This work was financially supported by Aqua-Fish CRSP Project.

\section{References}

AOAC 1980. Methods of analysis (13th ed.). Association of Official Analytical Chemists, Washington DC, USA. 1018p.

Boyd, C.E. 1990. Water quality in ponds for aquaculture. Alabama Agricultural Experiment Station, Auburn University, Alabama. 482p.

Briggs, M.R.P. and S.J. Funge-Smith 1994. A nutrient budget of some intensive marine shrimp ponds in Thailand. Aquaculture and Fisheries Management 25: 789-811.

DoFD 2011. Annual report-2011. Directorate of Fisheries Development, Balaju. Department of Agriculture, Ministry of Agriculture and Cooperatives, Government of Nepal.

Gowen, R.J., J.R. Brown, N.B. Bradbury and D.S McLusky 1988. Investigations into benthic enrichment, hypernutrification and eutrophication associated with mariculture in Scottish coastal waters (1984-1988). Report to the Highlands and Islands Development Board, Crown Estate Commissioners, Nature Conservancy Council, Countryside Commission for Scotland and Scottish Salmon Growers Association. 289p.
Jayasinghe, J.M.P.K and M.S.M.W. de silva 1993. Brackish water aquaculture in acid surface soil of Sri Lanka. Asian Fisheries Science 6: 341-345.

Khoi, L.V. and R. Fotedar 2010. Effects of stocking density on nutrient budget and growth of the western king prawn (Penaeus latisulcatus Kishinouye) in a recirculating aquaculture system. Aquaculture Research 41: 624-633.

Mandal, J.K. and M.K. Shrestha 2001. Effect of feed supplementation on growth and production of Nile tilapia in mixed size culture system. J. Inst. Agric. Anim. Sci. 21-22: 141-149.

Mishra, R.N. 2002. African catfish (Clarias gariepinus) as a predator for population control in mixed sex Nile tilapia (Oreochromis niloticus) farming. Department of Aquaculture, Institute of Agriculture and Animal Science, Rampur, Chitwan, Nepal. 93p. (M.Sc. Thesis)

Pandey, C.M., M.K. Shrestha, C.N.R. Yadav and S. Rai 2007. Productivity of carp polyculture system under farmers' pond condition in sub tropical Nepal. In IAAS Research Advances, Vol. 1 (Eds. R.B. Thapa and M.D. Sharma). IAAS, Rampur, Chitwan, Nepal. pp. 175-179.

Pandit, N.P., M.K. Shrestha, Y. Yi, J.S. Diana 2004. Polyculture of grass carp and Nile tilapia with napier grass as the sole nutrient input in the subtropical climate of Nepal. In New Dimension in Farmed tilapia, Proceedings of 6th International Symposium on Tilapia in Aquaculture (ISTA 6) (Eds. R. Bolivar, G. Mair and K. Fitzsimmons). pp. 558-573.

Pantha, M.B. 1993. Aquafeeds and feeding strategy in Nepal. In Farm Made Aquafeeds. Proceedings of the FAO/AADCP Regional Expert Consolation on Farm-Made Aquafeeds, 14-18 December 1992, Bangkok, Thailand. (Eds. M.W. New, A.G.T. Tacon and I. Csavas). FAO-RAPA/AADCP, Bangkok. pp. 24-60.

Perez-Velazquez M., M.L. Gonzalez-Felix, S Gomez-Jimenez, D.A. Davis and N. MiramontesHiguera 2008. Nitrogen budget for a low-salinity, zero-water exchange culture system: II. Evaluation of isonitrogenous feeding of various dietary protein levels to Litopenaeus vannamei (Boone). Aquaculture Research 39: 995-1004.

Pillay, T.V.R. 1999. Aquaculture Principles and Practices. Fishing New Books, Cambridge University Press, United Kingdom. 575p. 
S. Gurung, M.K. Shrestha and N.P. Pandit / Our Nature (2013), 11(2): 116-125

Pradhan, G.B.N. and M.B. Pantha 1995. Nepal Country Report (Annex 11-12). Report on a Regional Study and Workshop on the Environmental assessment and Management of Aquaculture Development. Food and Agriculture Organization (of the United Nations) and Network of Aquaculture Centers in Asia Pacific, Bangkok, Thailand.

Shrestha, M.K. and R.C. Bhujel 1999. A preliminary study on Nile tilapia (Oreochromis niloticus) polyculture with common carp (Cyprinus carpio) fed with duckweed (Spirodela) in Nepal. Asian Fisheries Science 12: 83-89.

Shrestha, M.K., R.L. Sharma, K. Gharti and J.S. Diana 2011. Polyculture of sahar (Tor putitora) with mixed-sex Nile tilapia. Aquaculture 319: 284-289.

Shrestha, T.K. 1997. The Mahaseer in the rivers of Nepal disrupted by dams and ranching strategies. Publ. Mrs. Bimala Shrestha, Kathmandu, Nepal. $271 \mathrm{p}$

Thakur, D.P. and C.K. Lin 2003. Water quality and nutrient budget in closed shrimp (Penaeus monodon) culture system. Aquaculture Engineering 27: 159-176.

Yadav, R.K., M.K. Shrestha and N.P. Pandit 2007. Introduction of Sahar (Tor putitora) in cage-cumpond integrated system of mixed-sex Nile tilapia (Oreochromis niloticus). Ournature 5: 52-59.

Yi, Y., C.K. Lin and J.S. Diana 2003. Hybrid catfish (Clarias macrocephalus x C. gariepinus) and Nile tilapia (Oreochromis niloticus) culture in an integrated pen-cum-pond system: growth performance and nutrient budgets. Aquaculture 217: 395-408.

Yi, Y., J.S. Diana, M.K. Shrestha and C. K. Lin 2004. Culture of mixed-sex Nile tilapia with predatory snakehead. In New Dimension in Farmed tilapia, Proceedings of 6th International Symposium on Tilapia in Aquaculture (ISTA 6) (Eds. R. Bolivar, G. Mair and K. Fitzsimmons). pp. 544-557.

Yoshida, S., D.A. Forno, J.H. Cock, and K.A. Gomez 1976. Laboratory Manual for Physiological Studies in Rice (3 ${ }^{\text {rd }}$ Ed.). International Rice Research Institute, Manila, Philippines. 61p. 